\title{
Kolmas rahvakunst
}

\begin{abstract}
Teesid
Eesti rahvakunsti on lisandunud uus valdkond - kujutav rahvakunst. Sümbioosne kolmas rahvakunst on arenenud professionaalsele kunstile omase pildilise traditsiooni ning rahvaliku mõtteviisi ja käsitööoskuse sulamina. Tänapäevased kujutava rahvakunsti loojad erinevad varasemast käsitöömeistrist subjektiivse, originaalse ja mittepraktilisele orienteeritud loomeviisi poolest. 18.-19. sajandil alanud linna- ja maarahva tihedam lävimine aitas kaasa rahvalike ja elitaarsete kunstivormide senisest kiiremale segunemisele. Sellest ajajärgust on pärit mitmed nn teise folkloori vormid, nagu näiteks slaavi lubokk, Ameerika limnerite maalid, naivistide pildid, Suure Prantsuse revolutsiooni aegne agitatsioonikeraamika, kaupluste käsitsi maalitud reklaamsildid ja fotoäride taustapildid. Viimastel aastakümnetel on kõikjal suurenenud mitteelitaarse kunsti huvi. USAs on tarvitusel mõiste kaasaegne (kujutav) rahvakunst, mille all vaadeldakse naivismi, autsaiderite kunsti, ruraalset käsitööd. Soomes kasutatakse külakunsti tähistamiseks lühendit ITEkunst (lühend sõnadest itse tehty elämä ('ise loodud elu resp. maailm'). Eestis on tuntud mõiste harrastuskunst. Eesti rahvakunsti külageeniused on Jaan Oad, Harri Aer, Leida Alliksaare, Adelbert Juks, Aleksander Tarvis jt.
\end{abstract}

Märksõnad: harrastuskunst, kujutav rahvakunst, limner, lubokk, sildimaalijad

Kui kunst (edaspidi peetakse silmas visuaalkunste) liigitada kaheks kategooriaks, rahvakunstiks ja professionaalseks kunstiks (professionaalse kunsti all mõeldakse edaspidi kunsti, mis loodi pärast kunstniku ameti eraldumist käsitöölise omast), jääb nende kahe vahele veel vaheala ehk nn kolmanda kultuuri kunst. Ala, mida Eestis pole kuigi palju uuritud, asub kõrgkultuuri (koolitatud, intellektuaalsetel teadmistel põhinev kultuur) ja rahvakultuuri (algses tähenduses koolitamata traditsioonil ja pärimusel põhinev kultuur), maa- ja linnakultuuri vahelises tsoonis, kord rohkem rahvakultuuri traditsioonidega haakudes, teinekord rohkem elitaristlikprofessionaalset kultuuri jäljendades.

Kultuurilises vahetsoonis võetakse professionaalsest kunstist jäljendatavate eeskujudena üle žanrid, süžeed, motiivid ja rahvakunstist endisaegsed käsitööoskused, vernikulaarsed materjalid ja mõtlemisviis. (Kunsti)hariduse ja oskuste puudumise, ruraalse mõt- 


\section{Sigrid Saarep}

teviisi ja erineva loomingulise motivatsiooni tõttu tekibki kahe kultuuri segunemisel omaette "kolmas kultuur" ehk "teine folkloor". Sellesse kultuuri kuuluvad rahvakultuuri uurija Valeri Prokofjevi järgi muu hulgas votiivmaalid (alates barokiajast), Poola 17.18. sajandi "sarmaadi portree" ja analoogsed nähtused mujal slaavi aladel, ameerika limnerite maalid, Vene kaupmeeste ja mõisnike portreed 18. sajandi I poolest 19. sajandi II pooleni, Suure Prantsuse revolutsiooni aegne agitatsioonikeraamika, lubokipildid, kaupluste, kohvikute jms sildid, tsirkuseafišid, fotoateljeede maalitud taustad ja 20. sajandi alguses esile kerkinud iseõppijatest kunstnikud ehk naivistid (Prokofjev 1983: 7-8).

Järgnevalt vaatleme lähemalt kolme nn teise folkloori nähtust: lubokki, sildimeistreid ja limnereid ning seejärel püüame uurida, mis on kaasaja rahvakunst ja missugune see on.

\section{Slaavi lubokk}

18. sajandi teisel poolel tekkis slaavi aladel rahvalik, puu- või vaskplaadile tehtud pilt - lubokk (tuleneb venekeelsest sõnast lub - 'niin'; lubok - 'puukoor, puukooretükk'). Tüüpiline lubokipilt oli plaadile kas graveeritud või maalitud. Kunstilise käsitöötoote valmistajad talupoegadest poolkunstnikud või ka linnakäsitöölised - tegid neid humoorikaid "ilupilte" mõisnikele, oma küla elanikele ja käsitöölaatadel müümiseks (Ostrovski 1983: 91). Peterburi akadeemias õppinud professionaalsete kunstnike töödest erinesid lubokitööd nii sisult kui ka vormilt nagu öö päevast.

Ehtne rahvalik lubokk sai alguse linnakeskkonnas, sealsetes käsitöökodades, kuid tema juured on siiski talupoeglikud ja pärit maalt, talurahva käsitöötraditsioonidest, kus talupoeglikku majapidamist kaunistati maalitud piltidega. Tihti olid maalitud ka lihtsad tarbeesemed, näiteks vokk "pildi asemel" seinal. Et linnakäsitöölised olid reeglina maalt linna rännanud pärisorjad, tekkis seal "uus" pildimaalimismeetod. Professionaalselt kunstilt võeti üle süžeed, motiivid ja teemad, mis sulandati oma keskkonda ja kohandati rahvapäraste talupoeglike arusaamade ja ideedega (Ostrovski 1983: 91-92).

Selliseid lubokipilte tellisid mõisnikud, kellel olid tihti oma pärisorjadest "hoovikunstnikud", kes tegid pilte nii mõisnikule kui ka kohalikele külaelanikele. Käsitöölistest pildimeistrid ei muutunud 
diletantideks ja lihtsalt jäljendajateks, sest nad säilitasid kohalikule folkloorile omase kujundliku mõtlemise, jäädes enamasti seotuks rahvakunsti sfääriga. Samuti tuleb vene "iseõppijate" kunstis ära märkida pikaajalisi ikoonimaalistraditsioone, mis kandusid osaliselt lubokki üle (Ostrovski 1983: 92).

Pildid olid mitmesugused, valdav oli siiski talupojatemaatika, enamasti idealiseeritud kujul, sest 18. ja 19. sajandi vahetuse sentimentalismi ja romantismi ajajärgul oli "talupojalüürika" moes. Veel esines nn ideaalse kangelase (Peeter I, kasakapealik Jermak, väepealik Mihhail Kutuzov) portree - žanr, millega mõisnikud armastasid oma ruume ehtida. Moodi läksid maalid nn inglise maitse järgi - jahistseenid lemmikkoerte ja -hobustega, samuti variatsioonid antiikkunsti teemadel ja piiblimütoloogial, mida kohalik kunstnik transformeeris oma töösse. Näitena võib tuua ühe 19. sajandi ilukirjandusest (Ivan Panajevi Akteonist) pärineva "luboki maitsele" vastava pildikirjelduse:

Kahel maalil kujutas kunstnik oma isandat, aga viimase käsul erinevates situatsioonides. Ühel pildil, mis võttis enda alla peaaegu kogu seina, istus isand suursugusel moel hobuse seljas, riietatud jahikostü̈̈mi, ja hoidis tagasi oma koeri just saarelt välja aetud emajänese peale jooksmast... Teisel ilmus ta lühikeses suvekuues, käes nuut, mõnuga vaatamas oma lemmiku, rüütliks rõivastatud narri peale, keda tallipoiss hobuse selga aitas. Kolmanda maali aineks oli lopsakas nümf, maalitud köögitüdruk Palaska järgi, ja põõsastest teda vaatav saatür (Ostrovski 1983: 92-96).

Sellised pildid väljendasid tolle ajajärgu vene rahvalikku maitset. Linnakultuuris kandsid lubokimaalid edasi talupoeglikku alamkeskklassi kultuuri (Shkarovskaya 1984: 689).

19. sajandi II poolel (mida mõjutas ka pärisorjuse kaotamine 1861. aastal, mil talupojakultuur hakkas jäljendama aristokraatlikku kultuuri ja sellega segunema), hakkasid talupojamaalid kaduma, asemele tulid töökodades trükitud graafilised pildid - litograafia ja foto. Lubokk muutus tsenseeritud, massidele mõeldud pildiks (Ostrovski 1983: 99). Kadus varasem ilmekus ja trükipressi kasutuselevõtuga tekkis masstoodang.

20. sajandi alguses pöördus osa vene avangardikunstnikke (nagu mujalgi Euroopas) traditsiooniliste kultuuride, keskaegse ja rahvakunsti poole. Venemaal tegutsesid tollal avangardistlikud rühmitu- 
Sigrid Saarep

sed, nagu näiteks Ruutu Soldat, kus vaimustuti ikoonimaalist, lubokist ja arhailisest disainist (Shkarovskaya 1984: 689).

\section{Inglise sildimaalijad}

Vaadeldes Inglismaa iseõppijate poolprofessionaalset kunsti ajajärgust 1750-1900, võib selles leida ühiseid jooni lubokiga.

18.-19. sajandi Inglismaal on võimalik tõmmata piirjoon selle vahele, mida võiks kutsuda vastavalt toorilikuks ja viigilikuks ${ }^{1}$ maitseks. Viigid kui ajaloolise tagapõhja ja traditsioonideta uued suurmaaomanikud püüdsid üle võtta Euroopa kultuuriuuendusi, samal ajal kui toorid (varasem gentry, mõisnikud ja vabatalupojad) jäid truuks vanale kehtivale ja kohalikule traditsioonile. Uus aristokraatia valis Euroopa, vana Inglismaa (Melly 1982: 7).

Tolle perioodi alguse anonüümsete meistrite tööd on suures osas dokumenteeriva iseloomuga jäljendavad olustikupildid.

18. ja 19. sajandi alguses viidi Inglismaal läbi agraarreform, levisid trükised, sealhulgas ka teaduslikud raamatud illustratsioonidega karja-, tõu- ja muudest loomadest. Agraarreform arendas ja tugevdas väikemõisnike eneseteadvust. Kui Euroopa orientatsiooniga suurmaaomanikud palkasid professionaalseid kunstnikke, siis väikemõisnikud ja farmerid kasutasid analoogselt Venemaa mõisnikega elamise dekoreerimiseks andekate kohalikus külas tegutsevate maalijate teenuseid (Melly 1982: 7).

On teada, et väga paljud pildimaalijatest kunstnikud olid elukutselt sildimaalijad. Alates 1625. aastast pidid kõik Londoni poed ja ärid kohustuslikus korras panema välja sildi, kuid 1763. aastal võeti vastu uus seadus, mis piiras siltide arvu linnatänavatel.

Pärast seda muutusid sajad sildimaalijad rändkäsitöölisteks. Osa neist leidis rakenduse väikemõisnike juures, maalides neile rammusaid lehmi ja lambaid.

1762. aastal organiseeris Inglismaa maalikunstnik ja graafik William Hogarth näituse, mida võiks pidada kunstiajaloos esimeseks naivismi või vähemalt naivismi eelkäijate näituseks. See oli Grand Exhibition of the Society of the Sign Painters. Näituse eesruumi riputas W. Hogarth sildi, kuhu oli kirjutatud Horatiuse tsitaat: Teie, keda lubatakse vaatama, ohjeldage oma naeru.

Naiivne folkloorne nägemine ja maalimine kadus Inglismaal 19. sajandil seoses kunstikoolide, kunstikursuste ja fotograafia le- 


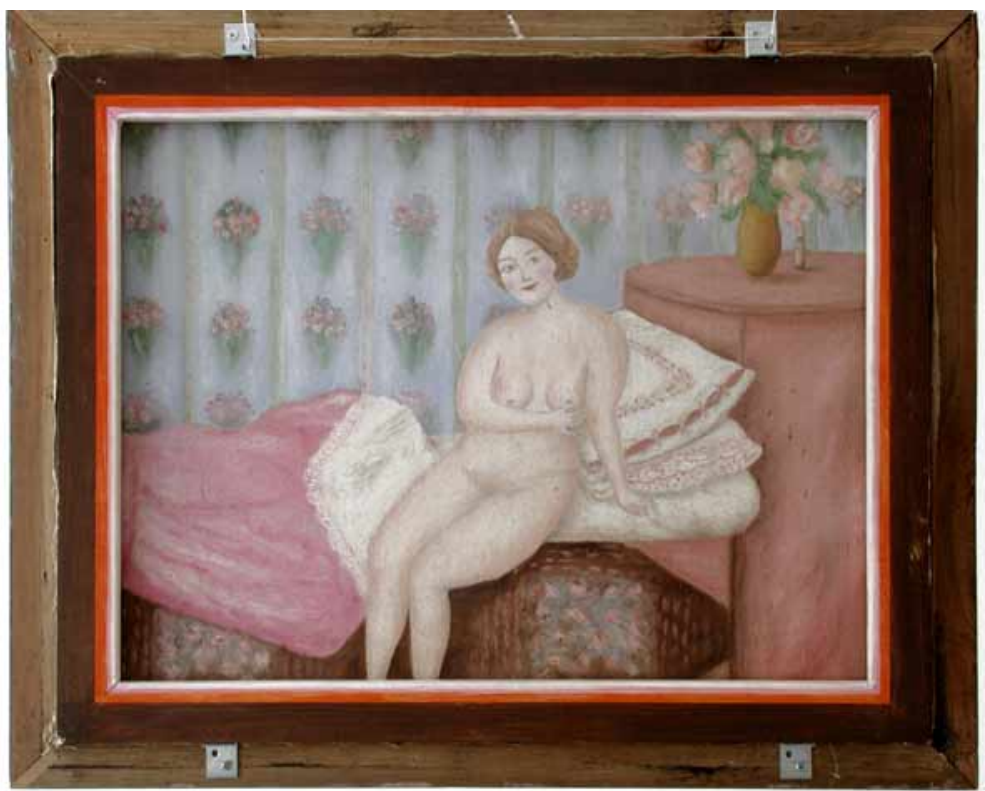

Joonis 1. Adelbert Juks. Akt. Õli.

vikuga. Peale tungis tööstuslikult produtseeritud kultuur (fotod, reprod), millele ei suudetud vastu seista. Naivism muutus spetsiifiliseks ja eraklikuks nähtuseks (Melly 1982: 9).

\section{Ameerika folk}

Võrdluses Euroopaga oli Põhja-Ameerikas iseõppijate side professionaalse kunstiga kaudsem. Pärast Ühendriikide eraldumist Briti koloniaalsüsteemist (1776. aastal võeti vastu iseseisvusdeklaratsioon) jäid "koolitatud" kunsti eeskujud Euroopasse. Et Ameerikas puudus kohalik professionaalne kunst euroopalikus tähenduses, on vahe naiivselt maalijate ja diletantide vahel raskemini määratav. Kunstiakadeemiad loodi alles 19. sajandil ning isegi seejärel õppis ja töötas enamik kunstnikke periooditi Inglismaal. Peaaegu kogu sisserändajate majapidamine, alates mööblist ja lõpetades piltidega, tuli neil endil valmistada; ka oli enamik pildimeistritest eri alade käsitöölised. Maaliti enamasti ümbritsevat või püüti jäädvusta- 


\section{Sigrid Saarep}

da oma isiklikku elu ja kaasajaloolisi sündmusi. Valdavalt olid need portreed, loodusvaated, vaikelud, olustikumaalid, allegooriad. Portreede maalimine domineeris 18. sajandi keskpaigani, seejärel lisandusid loodusvaated, hiljem olustikumaalid ja ajaloolised stseenid, mis 19. sajandi keskpaiku saavutasid suure populaarsuse.

Alates 17. sajandist kutsuti mööda Ameerikat rändavaid ja farmerite majapidamisi trafaretsete maalidega (portreede, loodusvaadete ja freskodega) dekoreerivaid kohalikke kunstnikke limneriteks (limners; ingl k to limn, 'maalima, (käsikirju) illustreerima'). Enamik limneritest olid käsitöölised, kellele see käsitööst märkimisväärselt eristumatu kunst oli oluline elatusallikas. Nagu keskaegsed kunstnikud ning Inglismaa ja Venemaa poolprofessionaalid, ei signeerinud limnerid oma töid. Nende kunsti tellijad pärinesid enamasti väikelinnadest ja küladest. "Moodsamates" suurlinnades telliti maalid välismaalt - seega Euroopast.

Kuni fotograafia sünnini töötasid limnerid fotograafi funktsioonis, fotograafia levides hakkas nende amet kaduma (Bihalij-Merin 1971: 41-42).

Nii vene lubokikunstnikud, inglise sildimaalijad kui ka limnerid ei olnud enam traditsioonilise rahvakunsti väljendajad, kuigi nad pärinesid valdavalt külakeskkonnast, kus asuvad rahvakunsti juured. Samas ei saa neid pidada ka naivistideks selle mõiste 20. sajandi tähenduses, sest selleks olid nad oma püüdega jäljendada professionaalseid kunstnikke liialt isikupäratud. Nn poolkunstnike oskuste, hariduse ja mõtteviisi juures said pildid naiivse väljanägemise ja kajastasid talupoeglikku, mitte linlikku mõtteviisi. Enamikule eespool mainitud meistritele olid omased rahvakunstiga edasi antud käsitöötraditsioonid ja osaline püüe jäljendada professionaalseid kunstnikke, kelle töödest võeti üle motiivid ja süžeed. Kõik see moodustas omalaadse segu rahvakunstist, professionaalsest kunstist ja kunstniku enda isikupärast.

Sellistel käsitööpiltidel olid üpris kindlad tellijad (väikemõisnikud, farmerid, jõukamad talupojad) nagu professionaalsel kunstilgi, kuid tellijate ja tellimuse täitjate maitses ja mõtteviisis olid segunenud rahvalik ja professionaalne kultuur. Erinevalt 18. ja 19. sajandi iseõppijatest loob 20. sajandi (vähemalt selle I poole) iseõppija ehk naivist juba enamasti isiklikust vajadusest, mitte ei täida kliendi tellimust. Ent seoses naivistide menu ja mitteprofessionaalse kunsti institutsionaliseerimisega on viimastel aastakümnetel ka naivistidelt ja teistelt nn väljaspool asujatelt hakatud kunsti ostma ja tellima. 


\section{Kunst rahva seas: kus siis loomad on?}

Müüt, et rahvakunst on midagi puutumatut-muutumatut, on meil senini visa püsima. Ometi on paljud rahvakultuuri uurijad ammu tõestanud, et rahvakunst ei ole hoolimata oma konservatiivsest loomusest isolatsioonis arenenud ega kõrgkunsti mõjusid vältinud.

Helmi Üprus on kirjutanud:

Tugeva säilitamise tendentsi kõrval ei ole rahvakunst oma arengu pikkade sajandite kestel seisnud mingis isoleerituses... Rahvakunstil on olnud pidevalt vahendajaid ning kokkupuuteid teiste sotsiaalsete kihtide, naaberkultuuride, kunstistiilide üldise arengukäiguga (Üprus 1969).

Näiteks Eesti triibuseelikud on mõjutatud ampiirist; Põhja-Eesti lilltikandid on saanud mõjutusi baroki, rokokoo ja klassitsismi eri etapidest, seal nähakse isegi katoliikliku Hispaania tikandikunsti sugemeid. Arvatakse ka, et Muhu pruuditanu kuju võis tulla piiskopimitrast (Pütsep 1991: 11-12).

Huvitava näite integratsioonist on hiljuti toonud meie tuntud mõisauurija Ants Hein, kes kirjeldab ühes artiklis Albu mõisas asuvat kahhelahju, mis on kaunistatud rikkaliku geomeetrilise ja barokiomase taimornamendiga. Ornamendi otseseks eeskujuks on olnud Põhja-Saksamaa talurahvaornamentika. Seega on ka talupojakunst kõrgkunstile mõju avaldanud, mitte ainult vastupidi (Hein 2004: 82-88).

Milline siis võiks olla meie teine rahvakunst? Vahest saab selle hulka arvata esimesi ajakirja- ja raamatuillustratsioone? Arvatavasti ka meie päevapiltnike juures kasutusel olnud maalitud taustu ja kauplusesilte. Kindlasti aga kuulub rahvakunsti hulka rahvalike (küla)kunstnike (osalt ka naivistideks kutsutute) looming.

Levinud arvamuse alusel peetakse tööstusrevolutsiooni lõpuleviimist 19. sajandi II poolel rahvakunsti lõpu alguseks. Odava masstoodangu levik muutis töömahuka ja aeganõudva käsitöö tegemise mõttetuks. Samuti ähmastusid linna- ja maakultuuri piirjooned.

Tuntud naivismiuurija Anatole Jakovsky on arvamusel, et naivism sündis ajaloolise ja sotsiaalse murrangu ajal, kus siirduti käsitööajast tööstuseaega. Inimesed tundsid, et jäävad mehhaniseeritud poolkunstilisest toodangust väljapoole (Ojanen 1983: 9). On arvatud, et tööstusühiskonna teke isegi forsseeris isetegemist, s.t 


\section{Sigrid Saarep}

käsitööd. Näiteks elas Põhja- ja Lääne-Eesti käsitööliikumine 20. sajandi vahetusel üle omalaadse taassünni (Viires 1998: 663).

Olgugi, et nii tööstus- kui ka tänases infoühiskonnas pole otsest vajadust enam "teada, kuidas asju tehakse-valmistatakse", on inimestel seniajani säilinud soov midagi ise luua. Kuigi me ostame eluks vajaliku uue asja vabaajakeskusest ehk hüpermarketist ning hangime info ja rahuldame suhtlustarve veebi ehk hüperraamatu abil, eelistab suur osa Eesti inimestest endale senini oma kätega kodu ehitada ja seda ise kujundada. Rääkida võime omaehitatud elamutest, omatehtud mööblist ja omamaalitud piltidest seintel. Suurejoonelisematel juhtudel on kogu elukeskkond enda loodud.

On loomulik, et pilditegemise traditsioon ei saanud rahva (pean edaspidi silmas eesti soost maalt pärit inimesi) sekka jõuda enne, kui nendel inimestel tekkis võimalus pilte näha. Eestis korraldati esimene kunstinäitus aastal 1798. Tallinnas Sauna tänavas krundil nr 374 pandi välja maalide järgi teostatud graafiliste lehtede näitus (Pütsep 1991: 46).

1870. aastatel said alguse ka Eesti kunstnike näitused (Johann Köler, August Weizenberg). Nendel näitustel olid publikuks siiski baltisakslased.

20. sajandi alguses rahvusliku liikumise tugevnedes hakati korraldama põllumeeste seltside näitusi ja nende raames ka kunstkäsitööd välja panema. 1906. aastal lisandus Tartu Eesti Põllumeeste Seltsi näituse juurde iseseisev (kujutav)kunsti osakond (J. Köler, Karl Ludvig Maibach, Ants Laikmaa jt). Näitusel oli "päris" kunstnike loomingu kõrval väljas ka iseõppijate töid, veel sai vaadata näiteks pildiraame ja muud käsitööd (Hinnov 1972: 10-13). Näitus osutus menukaks, kuigi osa publikust oli hämmingus ning küsis: “Aga kus siis loomad on?" (Hinnov 1972: 13).

Paralleelselt ülejäänud Euroopaga hakkasid 20. sajandi alguse eesti haritlased, sh kunstnikud rahvakunsti koguma ja ka kunstilisest aspektist väärtustama. Eesti, nagu ka teiste tärkavate rahvusriikide kunstis-kultuuris oli selle põhjuseks rahvuslike ideede levik ja oma rahvusliku identiteedi säilitamine koos uute euroopalike ideede vastuvõtuga. Mujal Euroopas, kus kõrgkunstil oli seljataga pikk ajalugu, olid põhjused teised. Modernismiaja uuendusmeelsed kunstnikud olid nende silmis end ammendanud akademismist tüdinenud ja otsisid kunstitegemiseks uusi lähtekohti. Modernism asus väärtustama nn pehmeid kvaliteete - intuitiivsust ja tundlikkust-, mida leiti eksootiliste kultuuride kunstist ja rahvakunstist. 
Sigrid Saarep

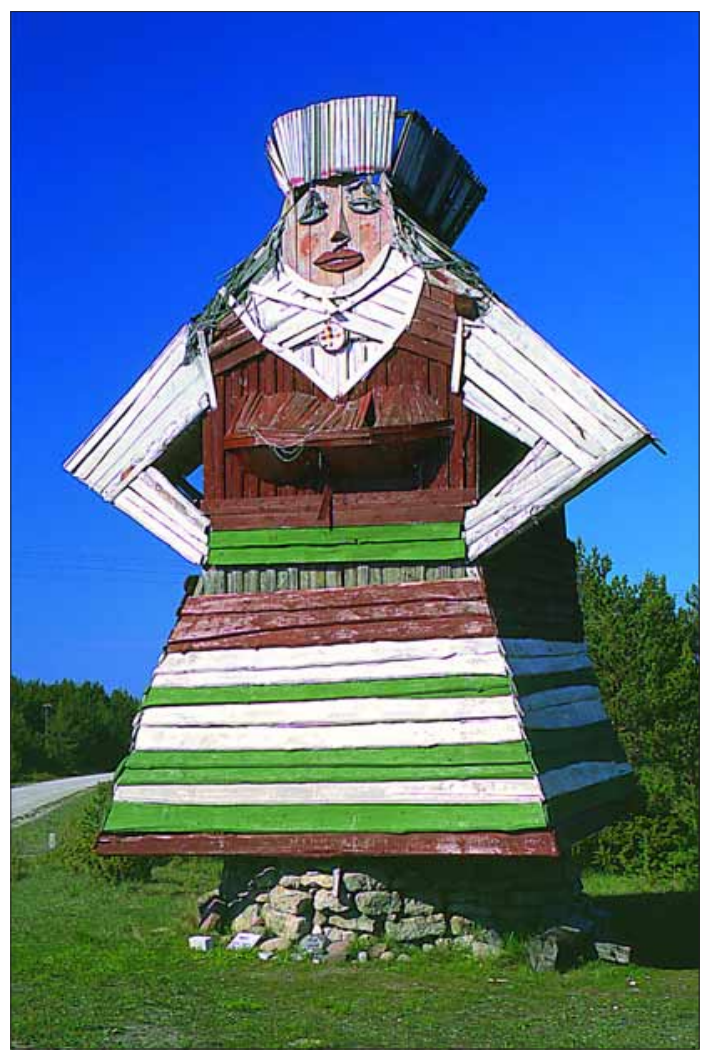

Joonis 2. Aleksander Tarvis. Tuulik Piret Saaremaal Ninasel.

20. sajandil tekkis rahvakultuuri ja kõrgkultuuri vahel nn kultuurivahetuslik sümbioos. Sellest ajajärgust alates on traditsioonilise rahvakunsti piirid muutunud. (Piiride hägustumine on toimunud ka muudes sfäärides.) Rahvakunsti mõjud on osaliselt leidnud koha professionaalses kunstis (rahvusromantism, Noor-Eesti liikumine; rahvakunsti traditsioon säilis ka 1950. aastate professionaalses tarbekunstis). Rahvakunst on saanud eelnenud perioodidega võrreldes veelgi enam mõjutusi ja/või asendunud rahvakunsti motiivide kasutamisega "kõrges" kunstis ja taidluses.

Nii nagu mujal maailmas, on ka meil Eestis tänapäeval olemas omad kunstnikud "rahva seast", kes jätkavad ja taasloovad "elavat" traditsiooni, olgugi harjumuspärasest veidi teisenenud kujul. 


\section{Sigrid Saarep}

Nende inimeste loodud kunsti on nimetatud naivismiks, autsaiderite kunstiks, kodukäsitööks, harrastuskunstiks, külahullude kunstiks, tagaaia kunstiks jms. Soomes rakendatakse külakunstnike kunsti tähistamiseks kunstnik Erkki Pirtola kasutusele võetud lühendit ITE-kunst, mis tähendab ise loodud elu resp. maailma (ITE = itse tehty elämä). Siinkirjutaja arvates on edaspidi kohane kasutada paralleelselt teiste humanitaarteadustega mõistet pärimuslik, seega pärimuskunst (vrd pärimusmuusika) või kaasaegne visuaalne rahvakunst. Mõiste kaasaegne rahvakunst (contemporary folk art) on eriti levinud Ameerika Ühendriikides, kus terminiga tähistatakse ruraalse, kuid erineva etnilise päritoluga iseõppinud kunstnike loomingut. Nõukogude ajal oli Eestis kasutusel tunnustusena mõeldud tiitel ENSV rahvakunstnik. Tiitli andis nõukogude süsteem silmapaistvale kultuuritegelasele ja sõna "rahvas" viitas sellele, et kunstnik kuulus nn nõukogude rahva sekka. (Toonane värdmõiste "nõukogude rahvas", kus etnilisi rahvusi "nagu ei olnud" ja selle asemel pidi eksisteerima "üksmeelne sõbralik nõukogude rahvas", annab sõnale "rahvakunstnik" kahjuks negatiivse kõrvaltähenduse.)

Heiki Pärdi on kirjutanud, et tänapäeval leidub üha vähem uurijaid, kes kasutavad rahvakultuuri mõistet, kui vaatlusaluseks objektiks on rahva tegelik kultuur. Tema arust on rahvakultuur teadlaste ja ideoloogide ühislooming konstruktsioonina, mitte rekonstruktsioonina sellest, "mis tegelikult oli”. H. Pärdi räägib ka linnaja maakultuuri tasandumisest ning sellest, et nüüdisajal on rahvakultuur koondunud pigem linnadesse, samuti viitab ta eestikeelse terminoloogia puudumisele ja ebaselgele kasutamisele nn rahvakultuuri uurimisalas (Pärdi 1998: 263-265). Selles suhtes nõustun temaga täielikult. Samuti on osa tänapäeval rahvakultuuri nime all peetavast (laadad, festivalid ja muud nn rahvaüritused) sageli kommertsimaiguline rahvakultuuri imitatsioon, koolitatud inimeste "diletantlik" või äriline lähenemine rahvakultuurile ehk siis kommertstaidlus. Rahvakultuuri ei saa esile kutsuda ega simuleerida, see on eelkõige elamisviis (vrd soomlaste enda loodud maailm). Mida suuremaks ja institutsionaalsemaks rahvakultuuriga tegelev kollektiiv muutub, seda vähem autentne ja rahvale omane on tema loodud kunst. Viimased probleemid tulevad tänapäeval päevakorda ka autsaiderite kunsti ehk ääreala kunsti puhul (autoriõigused, kunstiturg, nn libarahvakunst). Aga see on omaette teema.

Minu huvi teistsuguse, mitteõpitud kunsti vastu sai alguse umbes 1980. aastate teisel poolel ning puudutas kõigepealt arhitek- 
tuuri ja elukeskkonda. Üheks inspireerivaks raamatuks sai Tartu Kunstimuuseumist laenutatud rikkaliku fotomaterjaliga Fantastic architecture. Personal and eccentric visions (Schuyt \& Elffers 1980), kus vaadeldi arhitektuurina kõikmõeldavaid inimeste loodud ehitisi, objekte, struktuure. Suuresti sellel raamatul põhines ka minu edaspidine uurimis- ja kogumistöö Eestis. Algselt Tartu Ülikoolis bakalaureusetööna kaitstud uurimus kandis pealkirja Naivistlik arhitektuur ja arhitektuursed väikevormid kaasaegses Eestis (Saarep 1996). Kogutud materjal vormus 1997. aastal Tallinna Kunstihoone galeriis eksponeeritud näituseks "Vaba stiil" , 1999. aastal sai valmis 30 kunstniku loomingut ka tekstiga tutvustav kataloog (Saarep 1999).

Arhitektid ja skulptorid olid aga sageli ka maale ja joonistusi teinud. Näiteks Leida Alliksaare oli lisaks õues asuvale "zoopargile" katnud oma kodu seinad tapeedi asemel maalingutega. (Leida Alliksaarest on juttu kataloogis Vaba stiil (Saarep 1999)). Arhitektuurist maalide ja teiste visuaalse rahvakunsti vormide juurde jõudmine oligi järgmine samm.

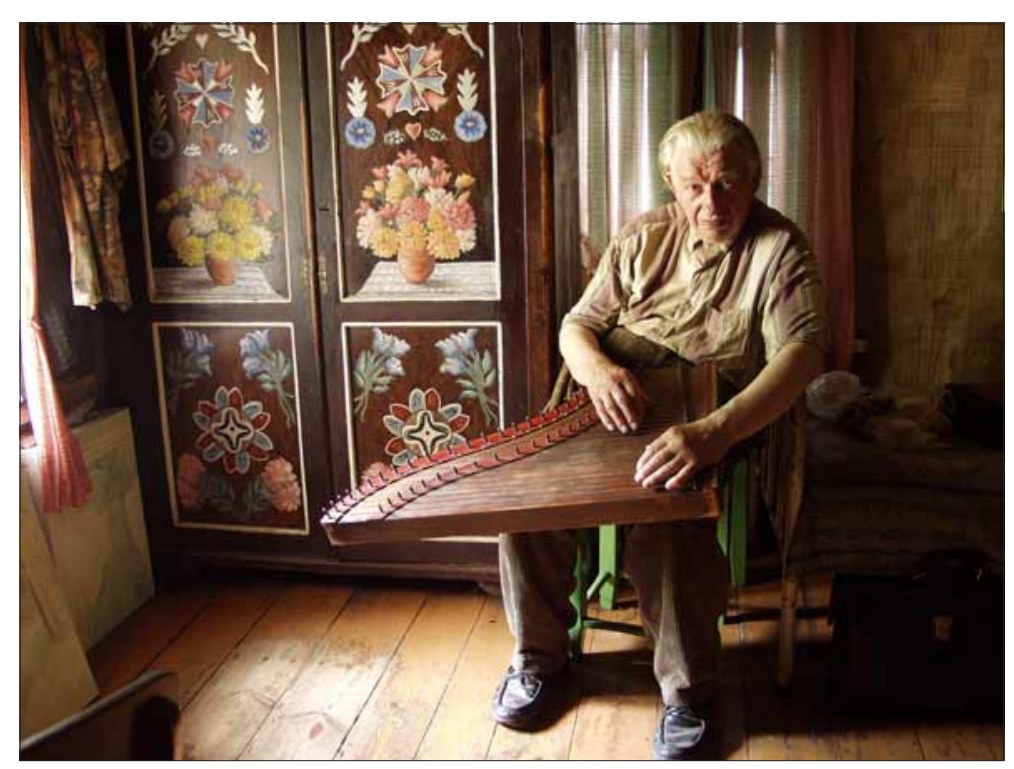

Joonis 3. Põlvamaa ilokunstnik Adelbert Juks oma kodus omamaalitud kapi ees kanneldamas. 
Sigrid Saarep

\section{Eesti omad ilokunstnikud}

Adelbert Juks on sündinud 1926. aastal Põlvamaal Himmaste külas. Käinud oma jutu järgi Teises maailmasõjas, sõdinud Vene poolel ja saanud sõjast kaasa invaliidsusgrupi. Sõja järel on A. Juks elanud edasi põliskodus, pidanud mesilasi ja harinud aeda. Samas pisikeses talutares elab ta vanapoisina koos oma vanema venna ja keskmise venna pojaga senini.

A. Juksil on "tõeline kunstnikuhing". Ta pole kunagi riigitööl käinud. Tema "tööks" on olnud maalimine ja pillimäng (Eesti Rahvaluule Arhiivis asuvad 1966. aastal tehtud Adelbert Juksi kandlemängu helisalvestused ). Kunstnik on kõikvõimalikud pinnad ja esemed oma majapidamises kaunistanud maalingutega. A. Juksi maalingute stiil on sümpaatne segu rahvaornamentikast ja isiklikust fantaasiast. Maalitud laetaladel kepslevad rahvatantsijad, suuremad laepinnad on kaetud geomeetriliste opkunsti meenutavate ornamentidega. Riidekapilt vaatavad vastu lillemotiivid, maastikud ja linnud segatuna rahvapäraste ornamentidega, samamoodi on dekoreeritud maja uksed ja ahi. Aknapiitade siseküljed on markeeritud riisikate, puravike ja marjakobaratega. Maja juures asuval kõrvalhoonel on omapärane ornamentaalne värvitud puitreljeef, kus on kujutatud maad ja taevast.

Lisaks on Adelbert Juks teinud õlimaale. Valdavalt on ta kujutanud maastikke, naisfiguure ja -akte ning lilli. Kui aktide puhul on eeskujudena aimata kunstiraamatute reproduktsioone, siis maastikud on maalitud otse loodusest.

A. Juksi maalingud on harmoonilised ja stiilsed, mis on omane ka meie varasemale rahvakunstile. Adelbert Juks on insiitne kunstnik rahva seast ja puhas ilokunstnik. Kui küsisin kunstnikult, miks ta seda kõike teeb, s.t maalib, vastas ta, et niisama ilo pärast. A. Juksi jutu järgi teadis tema ema väga palju rahvalaule, neid käidi tema juures salvestamas.

Orissaares 1920. aastal sündinud kunstnik Harri Aer hakkas pensionile jäädes mustrilisi ristpistetehnikas seinapilte ja vaipu tikkima. Lõngad värvis ise, mustrid mõtles välja ise, hiljem käisid külanaised temalt mustreid "laenamas".

Kui A. Juks kasutab rahvakunstis nn uut tehnikat, maalikunsti ja tahvelmaali ning kujutatu on stilistiliselt lähedane rahvakunstile, siis H. Aeru puhul on vastupidi - tehnika (tekstiiltikand, vaip) 


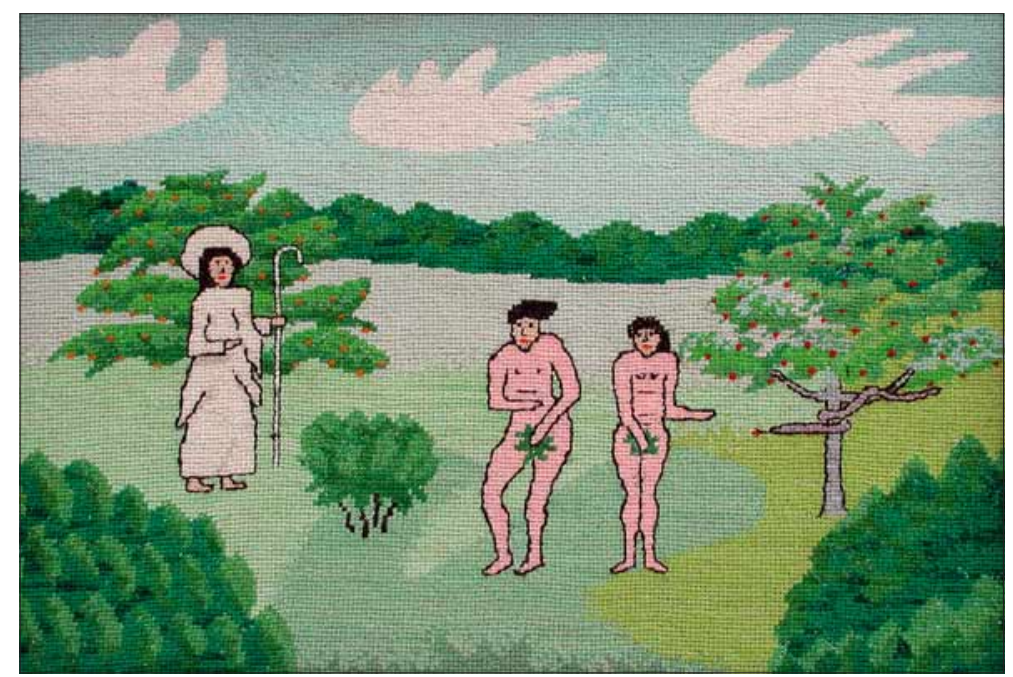

Joonis 4. Harri Aer. "Paradiisist väljaajamine". Tikand.

on traditsiooniline, aga kujutiste loomisel on autor lähtunud peamiselt fantaasiast. Temaatiliselt jagunevad Harri Aeru tööd külaelu piltideks (väga sage naivistide puhul), kirikuhooneid kujutavateks, loomamuinasjuttude järgi looduiks ja piibliainelisteks. Autorile pole olnud mingi vaev sulatada piibliaineline Aadama ja Eeva lugu oma kaasaegsesse folkloori ja saare kohalikku atmosfääri.

Kirjeldame ühte pilti: Jumal saadab seni kadakate vahel mõnusalt aega veetnud Aadama ja Eeva hurjutades paradiisiaiast välja. Paradiisiaed aga sarnaneb kahtlaselt Saaremaa kiviaiaga. Pildi allservas paikneb haukuv koer, kes on omakorda patustajaid paradiisist välja ajamas. Kõige krooniks lendab taevas kurg, titepamp noka vahel.

Harri Aer on üks vähestest tänapäeva rahvakunstnikest, kes on pälvinud oma töö eest avaliku tunnustuse: 1996. aastal määrati talle Eesti Rahvuskultuuri Fondi loominguline stipendium.

Saaremaa Tagaranna mees Aleksander Tarvis (1915-1999) sõitis eluaeg merd ega saanud kunagi lahti armastusest laevade ja mere vastu. Pensionile jäädes otsustas endine meremees oma kire piltidesse panna. Aleksander Tarvis on maalinud mitusada tormisel merel seilava laeva pilti, mis hiljem on purjetanud nii Soome, Rootsi kui ka Mandri-Eestisse. Kümmekond pilti asuvad kohalike külaelanike ja perekonna käes. 


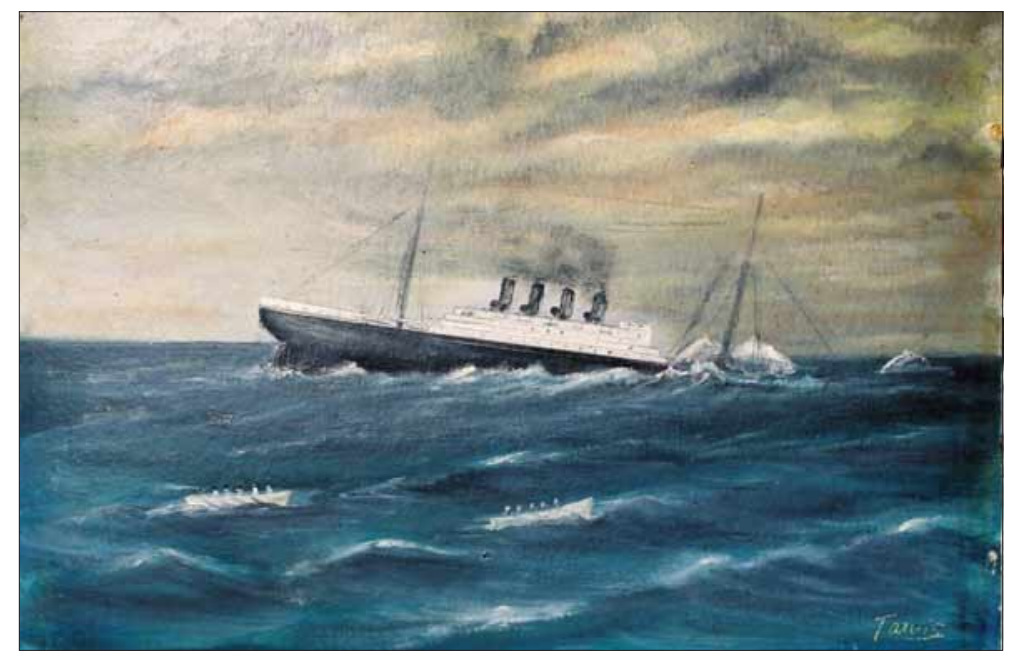

Joonis 5. Aleksander Tarvis. "Titaaniku hukk”. Õli.

Aleksander Tarvisega kohtusin aastaid tagasi, uurides pukktuulikutena kujutatud mehe ja naise ehituslugu. A. Tarvise jutu järgi tellis režissöör Mark Soosaar 1980. aastate alguses oma filmi "Pühapäevamaalijad" tarbeks nende kujude püstitamise. A. Tarvise ja kohalike külameeste abiga said Ninase tuulikud selga "rahvarõivad". Praegu teatakse saare muinaskangelaste Pireti ja Tõllu nime kandvaid tuulikuid kui kohalikke vaatamisväärsusi.

Traditsiooniline varasem rahvakultuur ei ole senini kuulunud minu huvisfääri. Seetõttu on mul ehk suurem vabadus vaadelda naiviste ja teisi iseõppinuid rahvakunsti ja pärimuskunsti kontekstis. Lisaks annab sellele õigustuse juba teiste uurijate tehtud töö (vt Prokofjev 1983). Samas on kunstiteoreetiline mõte väitnud, et mitte ainult rahvakunst vaid igasugune kunst põhineb traditsioonil (Bernstein 1990). Samuti on kunstiuurijad tõstnud 20. sajandil professionaalse kunsti kõrvale võrdseina ürgaja, keskaja ja rahvakunsti.

Minu huvi "koolitamata" kunsti vastu ei ole objektiivse uurija jahe huvi, vaid subjektiivne ja isiklik. Iseõppinud "metsikute" loomingus peituv info kommunikeerub minu tõekspidamiste ja maailmavaatega loomulikumalt kui koolitatud kõrgkunst. 


\section{Sigrid Saarep}

Rahvakunstnikud (neid on märksa rohkem kui antud tekstis sai mainitud) tegutsevad rahva hulgas edasi ega hooli sugugi sellest, mis nimetust haritud uurija tänapäeval tema kunsti eritlemiseks kasutab. Olgu selleks pärimuskunst, esimene, teine või kolmas rahvakunst.

\section{Kommentaar}

${ }^{1}$ Toorid ja viigid olid erakonnad 17.-19. sajandi Inglismaal.

\section{Kirjandus}

Bernstein, Boris 1990. Kunstiteadus ja kunstikultuur: [artiklite kogumik]. Tallinn: Kunst.

Bihalij-Merin, Oto 1971. Modern Primitives: Naive painting from the late seventeenth century until the present day. London: Thames and Hudson.

Hein, Ants 2004. Albu: Lisandeid ühe 18. sajandi mõisamaja portreele. Kunst 1, lk 82-88.

Hinnov, Virve 1972. Esimesed eesti kunstinäitused. Tartu Kunstimuuseumi almanahh 3. Tartu: [Tartu Riiklik Kunstimuuseum], lk 9-24.

Melly, George 1982. The Naïve Thread in British Art. Art and Artists: International Art Guide 3, lk 7-9.

Ojanen, Risto 1983. Kuvien lempeä kapina: Suomalaisia naivisteja. Helsinki: Otava.

Ostrovski 1983 = Островский Григорий. Из истории русского городского примитива второй половины 18.-19. в. Прокофев, Валерий (koost \& toim). Примитив и его место в художественной культуры Нового и Новейшего времени. Москва: Наука, lk 78-102.

Prokofjev 1983 = Прокофев, Валерий. О трех уровнях художественной культуры Нового и Новейшего времени: $\mathrm{K}$ проблеме примитива и изобразительных искусствах. Прокофев, Валерий (koost \& toim). Примитив и его место в художественной культуры Нового и Новейшего времени. Москва: Наука, lk 6-29.

Pärdi, Heiki 1998. Mõistetest etnograafia, etnoloogia ja rahvateadus ning eesti etnoloogiast. Akadeemia 2, lk 252-266.

Pütsep, Ervin 1991. Kunstielu Eestimaal I: Kuni 1920. aastani. Acta Universitatis Stockholmiensis. Studia Baltica Stockholmiensia 7. Stockholm: 


\section{Sigrid Saarep}

Centre for Baltic Studies at the University of Stockholm \& Almqvist \& Wiksell International.

Saarep, Sigrid 1996. Naivistlik arhitektuur ja arhitektuursed väikevormid kaasaegses Eestis. Bakalaureusetöö. Tartu: Tartu Ülikool. Käsikiri Tartu Ülikooli folosoofiateaduskonna ajaloo osakonna kunstiajaloo õppetoolis.

Saarep Sigrid 1999. Vaba stiil: Arhitektuur ja aiaskulptuur = Free Style: Architecture and garden sculpture. Tallinn:Tallinna Kunstihoone.

Schuyt, Michael \& Elffers, Joost (koost) 1980. Fantastic architecture: Personal and eccentric visions. New York: Abrams.

Shkarovskaya, Natalja 1984. Naive Art in the USSR. Bihalji-Merin, Oto \& Tomaševic, Nebojša-Bato (toim). World encyclopedia of naive art: Hundred years of naive art. Secaucus (New York): Chartwell Books, lk 689.

Viires, Ants 1998. Tagasivaade. Viires, Ants \& Vunder, Elle (koost ja toim). Eesti rahvakultuur. Tallinn: Eesti Entsüklopeediakirjastus.

Üprus, Helmi 1969. Eesti rahvakunst kunstiajaloo aspektist. Etnograafiamuuseumi aastaraamat XXIV. Tallinn: Valgus, lk 7-40. 